\title{
Go Preventive or Go Home - The Double Nature of MREL
}

by

\author{
EdOARDO D. MARTINO* \\ and \\ Katarzyna M. Parchimowicz**
}

\begin{abstract}
Bank Resolution is considered a cornerstone of the post-crisis financial regulation; however, it is also widely considered ineffective and inefficient in handling bank failures. This article analyses the preventive potential of the resolution framework, specifically focusing on the minimum requirement for own funds and eligible liabilities (MREL). We argue that MREL has a double nature. On the one hand, it should ensure the feasibility of resolution in case of a bank failure. On the other hand, it aims at restricting the funding model of banks, similarly to the other (preventive) capital requirements. By analysing the 2019 reform of the EU banking regulation, we contend that MREL represents an important complement to the rest of the preventive regulatory framework and that the latest reform unleashes such potential. We demonstrate that the new rules on MREL determination and enforcement allow the resolution authority to look after the build-up of systemic risk. The analysis reveals that MREL can serve both micro- and macro-prudential purposes. Finally, we argue that the current institutional architecture represents the main impeding factor for the new regulation to efficiently work, curbing the positive preventive potential of MREL.
\end{abstract}

Keywords: BRRD II, Bank Resolution, MREL, Preventive Regulation, Macro-Prudential Regulation

JEL Codes: G21, G28, K23

* Postdoctoral Researcher at the Amsterdam Center for Law \& Economics, Research Associate at European Banking Institute.

** Postdoctoral Researcher at the University of Wroclaw, Young Researcher at the European Banking Institute.

Acknowledgement: Katarzyna Parchimowicz gratefully acknowledges the support by the Polish National Science Centre (UMO-2020/37/N/HS5/00119).

We wish to thank Elena Ghibellini, Georgios Pantelias, Francesco Pennesi, Alvaro Pereira and two anonymous referees. A previous version of this article was presented at EBI YRG Virtual Workshop in September 2020. Helpful comments by participants are gratefully acknowledged. Usual disclaimers apply. 
1. Introduction . . . . . . . . . . . . . . . . . . . . . . . 609

2. From FSB's Key Attributes to EU Banking Reform Package . . . . . . . . . . 612

2.1. FSB's Key Attributes and TLAC . . . . . . . . . . . . . . . . . . . . . . 612

2.2. BRRD as Implementation . . . . . . . . . . . . . . . . . . . . . . . . 614

2.3. Banking Reform Package as a Way Forward . . . . . . . . . . . . . . 616

3. Two faces of MREL . . . . . . . . . . . . . . . . . . . . . . 617

3.1. In Resolution . . . . . . . . . . . . . . . . . . . . . . . . . . . . 617

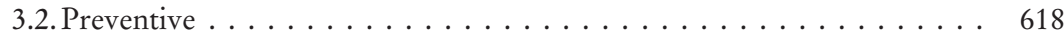

4. MREL after the Banking Reform Package . . . . . . . . . . . . . . . . . . . . 620

4.1 Capital Requirements and Eligible Liabilities . . . . . . . . . . . . . . . . . 620

4.2 MREL Determination . . . . . . . . . . . . . . . . . . . . . 625

4.3 MREL Breaches . . . . . . . . . . . . . . . . . . . 630

5. Assessment . . . . . . . . . . . . . . . . . . 634

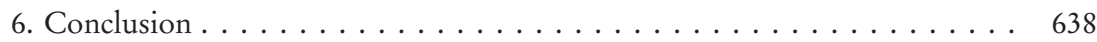

\section{Introduction}

In the wake of the Global Financial Crisis, the European policy-maker among many other interventions - launched a new framework for the recovery and resolution of failing banks whose main goals were to end the too-big-tofail phenomenon and avoid the use of public funds to bailout failing banks. ${ }^{1}$

The idea underpinning the new resolution framework was that bank insiders, shareholders and unsecured bondholders (bail-in capital), should bear the losses of bank distress and internally recapitalise the bank through the writedown or conversion into equity of their claim. ${ }^{2}$ To achieve such an ambitious goal, a failing bank must have enough bail-in capital to absorb losses and recapitalise the bank. Thus, the Bank Recovery and Resolution Directive (BRRD) ${ }^{3}$

1 Herman van Rompuy, "The European Council in 2012", Publications Office of the EU (2013), p. 8, https://www.consilium.europa.eu/media/21325/euco-annualreportupdated-2012-en.pdf, accessed 10 June 2021.

2 For a thorough explanation of the resolution framework and the associated resolution powers, see Karl-Philipp Wojcik, "Bail-in in the Banking Union”, Common Market Law Review 53 (2016), 91.

3 We will use the following terminology and abbreviations. If referring to the original BRRD of 2014 (Directive 2014/59/EU of the European Parliament and of the Council of 15 May 2014 establishing a framework for the recovery and resolution of credit institutions and investment firms and amending Council Directive 82/891/EEC, and Directives 2001/24/EC, 2002/47/EC, 2004/25/EC, 2005/56/EC, 2007/36/EC, 2011/35/EU, 2012/ 
introduced the minimum requirement for own funds and eligible liabilities (MREL), a minimum amount of bail-in capital to be held at all times to ensure the feasibility of bank resolution. ${ }^{4}$

Hence, the primary purpose of MREL consists of ensuring the feasibility of resolution once the bank is already "failing or likely to fail". ${ }^{5}$ In this article we contend that MREL has not only an ex-post purpose and we demonstrate that the ex-ante effects of MREL can be important for preventive purposes, both in a micro-prudential and macro-prudential perspective. In studying the MREL's double nature, ex-ante and ex-post, we will focus on the new MREL framework resulting from the most recent reform of EU banking law framework. ${ }^{6}$ We claim that the new regime unleashes the preventive potential of MREL and actually demonstrates legislator's current intention to perceive MREL as a preventive tool as well.

This article is not the first to propose the ex-ante effect of MREL and, more in general, of the resolution framework. However, most of the studies carried out so far focused on the ability of the new framework to re-install market discipline in bank debt financing.? Bail-inable creditors - so the argument runs should anticipate the probability of future losses in resolution and factor these losses in when pricing the instruments. ${ }^{8}$ This, in turn, should make banks more

30/EU and 2013/36/EU, and Regulations (EU) 1093/2010 and (EU) 648/2012, of the European Parliament and of the Council) we shall use the abbreviation 'BRRD.' In turn, if referring to the version of BRRD including the recent amendment (Directive (EU) 2019/879 of the European Parliament and of the Council of 20 May 2019 amending Directive 2014/59/EU as regards the loss-absorbing and recapitalisation capacity of credit institutions and investment firms and Directive 98/26/EC) we shall use the 'BRRDII' term.

4 Recital 79 BRRD.

5 The designation of a bank as "failing or likely to fail" constitutes one of the conditions to start a resolution procedure. The resolution should also be in the public interests and no alternative private solution should be available. See art. 32 BRRDII.

6 See Section 2.3 of this article.

7 See for instance, among many others, Emilios Avgouleas/Jay Cullen, "Market discipline and EU corporate governance reform in the banking sector: Merits, fallacies, and cognitive boundaries.” Journal of Law and Society, 41/1 (2014), 28; Tobias Tröger, “Too Complex to Work: A Critical Assessment of the Bail-in Tool under the European Bank Recovery and Resolution Regime", Journal of Financial Regulation 4 (2018), 35; Tobias Tröger, "Why MREL won't help much: minimum requirements for bail-in capital as an insufficient remedy for defunct private sector involvement under the European bank resolution framework", Journal of Banking Regulation 21 (2020), 64.

8 Jianping Zhou/Virginia Rutledge/Wouter Bossu/Marc Dobler/Nadege Jassaud/Michael Moore, "From Bail-out to Bail-in: Mandatory Debt Restructuring of Systemic Financial Institutions”, IMF Staff Discussion Note, 24 April 2012, p.20, https://www.imf.org/ external/pubs/ft/sdn/2012/sdn1203.pdf, accessed 10 June 2021. 
sensitive to excessive risk-taking to keep their cost of funding low. The market discipline effect of the BRRD has been harshly criticised and never completely proved.

We propose that MREL can bring about positive (micro)preventive effect through a different channel; namely the powers granted to the resolution authority concerning MREL determination and the enforcement of MREL breaches. The article also shows that the MREL ex-ante effect is not limited to micro prevention, but MREL can also stir macro-preventive effects and curb the build-up of systemic risk in good times complementing the other sources of macro-prudential regulation. ${ }^{9}$

In this regard, financial crises have long-ago been conceptualised as endogenously generated by inherently instable financial institutions that take excessive risk during economic expansions. ${ }^{10} \mathrm{~A}$ corollary of this theory postulates that regulation of financial institution will tend to be procyclical, i.e. too lax during the upward phase of the credit cycle and too strict in the downward. ${ }^{11}$ The article shows that the new provisions on MREL determination and enforcement of MREL breaches allow the resolution authority to account for macroeconomic considerations. In this regard, our article complements the recent proposal of influential economists claiming for an ex-post macro-economic approach to resolution, relaxing the bail-in rule when a resolution happens in the midst of a systemic crisis. ${ }^{12}$

In line with this approach, the Single Resolution Board (SRB) took "a pragmatic and flexible approach" in setting MEL targets during the Covid-19 crisis, postponing their implementation when necessary. ${ }^{13}$ While we welcome this

9 The main macro-prudential tools are the capital buffers disciplined in Art. 128-140 of the Capital Requirement Directive, Directive 2013/36/EU of the European Parliament and of the Council of 26 June 2013 on access to the activity of credit institutions and the prudential supervision of credit institutions and investment firms, amending Directive 2002/87/EC and repealing Directives 2006/48/EC and 2006/49/EC, as modified by the Directive (EU) 2019/878 of the European Parliament and of the Council of 20 May 2019 amending Directive 2013/36/EU as regards exempted entities, financial holding companies, mixed financial holding companies, remuneration, supervisory measures and powers and capital conservation measures.

10 Hyman Minsky, Can “It” Happen Again? Essays on Instability and Finance, 1982.

11 Rafael Repullo/Javier Suarez, "The Procyclical Effects of Bank Capital Regulation", The Review of Financial Studies 26 (2013), 452, 472.

12 Thorsten Beck/Dejan Radev/Isabel Schnabel, "Bank Resolution Regimes and Systemic Risk”, CEPR Discussion Paper 14724 (2020).

$13 S R B$, Communication from the SRB on the potential COVID-19 outbreak relief measures, https://srb.europa.eu/sites/default/files/srb_letter_on_potential_covid-19_ outbreak_relief_measures_0.pdf, accessed 06 June 2021. 
flexible approach during the crisis, we want to underline from the very beginning that it should be complemented by a more rigid approach in good times so as to unleash the preventive potential of the resolution framework as will be discussed in the proceeding of the article.

The remainder of the article is structured as follows. Section 2 describes the development of the resolution policy and the requirements to hold bail-in capital, from the international standards issued by the Financial Stability Board (FSB) to the newest reform of the EU banking law. Section 3 introduces the main theoretical construct of the article, analysing both the ex-ante and ex-post nature of MREL. Section 4 substantiates that theoretical framework and analyses the MREL new legal regime. Section 5 critically assesses the findings of Section 4 and highlights how the current EU institutional architecture may hinder the efficiency and effectiveness of the new framework. Section 6 concludes.

\section{From FSB's Key Attributes to EU Banking Reform Package}

In the lack of credible resolution regimes in place during the Global Financial Crisis, governments all around the world had to face bank failures using tools at their disposal. US regulators' strategy resembled the so-called Powell Doctrine, inspired by post-Vietnam war tactic. It meant 'overwhelming use of force with a clear way out. ${ }^{14}$ Only in case of financial institutions this 'force' meant taxpayers' money. State guarantees and different forms of bailout were also present in case of European bank failures - from Northern Rock to Fortis and Dexia. The mistrust between home and host countries of multinational financial companies started the blame game ('we will not import your cancer"15). The need for international standards on bank resolution - ideally followed by national implementation - became evident.

\subsection{FSB's Key Attributes and TLAC}

International community addressed the banking resolution issues (or rather non-existence of banking resolution scheme) already in 2011 and published Financial Stability Board's (FSB's) Key Attributes of Effective Resolution Re-

14 Adam Tooze, Crashed: How a Decade of Financial Crises Changed the World, 2019, p. 338 .

15 Words the Chancellor of the Exchequer Alistair Darling said to Treasury Secretary Henry Paulson, as a justification for refusal to facilitate Barclays' purchase of Lehman Brothers. 
gimes for Financial Institutions (KA, updated in 2014). ${ }^{16}$ This document not only acknowledged the need for special resolution regime for financial institutions, distinct from corporate insolvency law, but also set out a framework to be implemented by national regulators.

First, it stresses the need for designation of a resolution authority. Further, in addition to general resolution powers, ${ }^{17}$ the KA include detailed description of three main tools: transfer of assets and liabilities, bridge institution and the most innovative bail-in tool. The latter allows for debt to be written down or converted into equity. In other words, it forces shareholders and creditors to bear losses, it 'bails them in'. As this procedure was expected to raise eyebrows from the outset, FSB also braced KA with safeguards, such as segregation of client assets or 'no creditor worse off' principle.

As the issue of contagion and systemic risk has become especially relevant since the crisis, the KA did not omit the aspect of global systemically important financial institutions (G-SIFIs). Cross-border cooperation between home and host resolution authorities, as well as specific requirement of recovery and resolution planning constitute two main improvements encompassed by the FSB's document. However, the KA do not elaborate on the issue of bail-inable capital, that would ex-ante enhance credibility of resolution tools.

To address this shortcoming, the FSB issued the 'Principles on Loss-absorbing and Recapitalisation Capacity of G-SIBs in Resolution' along with its Total Loss Absorbing Capacity (TLAC) Term Sheet. ${ }^{18}$ Its goal is to establish a framework for systemically important banks, depriving them of their 'too big to fail' feature and ensuring public funds will not be used in resolution. ${ }^{19}$ Thus, TLAC should be set on firm-by-firm basis by national regulators, but taking into account the internationally recognised floor of $18 \%$ of the resolution group's risk-weighted assets and $6.75 \%$ of the Basel leverage ratio denominator. ${ }^{20}$ Additionally, TLAC is to be held in addition to minimum capital requirements (and the buffers) ${ }^{21}$ and TLAC liabilities need to fulfil specific eligibility

16 FSB, Key Attributes of Effective Resolution Regimes for Financial Institutions, October 2014.

17 Para. 3.2 of KA.

18 FSB, Principles on Loss-absorbing and Recapitalisation Capacity of G-SIBs in Resolution. Total Loss-absorbing Capacity (TLAC) Term Sheet, November 2015.

19 Ibid., Foreword.

20 The Basel leverage ratio denominator is simply risk-independent exposure measure, used to calculate leverage ratio. Also, the above mentioned levels will be applicable from 2022 - until then lower standards are applied: 16\% will be a minimum for RWA measure and $6 \%$ for leverage.

$21 F S B$, TLAC (fn.18), para. 6. 
criteria in order to be counted towards this threshold. ${ }^{22}$ The FSB also compiled a closed list of exclusions from TLAC, ${ }^{23}$ including for instance insured deposits, short-term deposits and liabilities arising from derivatives. These TLAC features, the stacking order and quality of liabilities, and their implementation into EU law are analysed below and should be perceived as especially relevant in the context of ex-ante impact of resolution-related capital.

\section{2. $B R R D$ as Implementation}

The original Bank Recovery and Resolution Directive of 2014 constituted EU's implementation of FSB's standards. It covered comprehensively all aspects addressed in KA (resolution and recovery planning, resolution tools, establishment of resolution authorities), as well as adopted the European's take on bail-in capital - minimum requirement for own funds and eligible liabilities $(\mathrm{MREL})^{24}$ - even before the FSB's TLAC was officially agreed on.

Despite some differences, MREL and TLAC share the same main function: to absorb losses if the financial institution is to be resolved. ${ }^{25}$ However, they are not identical. MREL is binding for all institutions encompassed by the BRRD and TLAC only for G-SIBs. Furthermore, the latter is supposed to be set at an individual level above the prescribed minimum, in turn the former is also prescribed on a case-by-case basis by the resolution authorities, but without predefined minimum threshold over regulatory minima. ${ }^{26}$ There are also differences when it comes to eligibility criteria, ${ }^{27}$ or consequences of breach. ${ }^{28}$

After its adoption, the BRRD was dubbed as giving 'a clear set of rules, ${ }^{29}$ and MREL was perceived as 'part of the toolbox that allows us [SRB] to restore the principles of the market economy to the banking sector. ${ }^{30}$ However, as time

$22 F S B$, TLAC (fn.18), para. 7 and 9.

23 Ibid., para. 10.

24 EU MREL was adopted even before the FSB's TLAC was announced, but it is widely perceived as analogous measure (only apart from broader scope of application not limited to G-SIBs only).

25 For a detailed analysis of the difference between MREL and TLAC in the first version of the BRRD, see Tom Young, "Why TLAC and BRRD Discrepancies Will Fade", International Financial Law Review, 11 May 2015.

26 Art. 45 (6) BRRD, now art. 45c BRRD II.

27 See Table 2 in Tröger, JBR 2020, 64 (fn. 7), 70.

28 Detailed analysis of differences between TLAC and MREL is beyond the scope of this contribution.

29 Elke König, Speech during Press Breakfast on 21st of January 2016, https://srb.europa. eu/sites/srbsite/files/21012016_srb_opening_ek_final.pdf, accessed 10 June 2021.

30 Ibid. 
passed and this legal act's factual efficiency has been challenged by troubled Spanish and Italian banks, ${ }^{31}$ more and more criticism fell on its solutions and EU legislature. Some raised doubts on harmonization struggles, ${ }^{32}$ but main concerns were more material and could be divided into three groups - the ones regarding bail-in, a subgroup on MREL and the general 'too big to fail' issues. The first set of problems included uncertainty regarding deposits' hierarchy in insolvency and character of bail-inable depositors (their retail nature). The BRRD treats practically all savers, apart from small, insured depositors, as investors. Hence, they all incur losses in case of bank's failure. ${ }^{33}$

As for MREL, many argued, that it is in fact doubling capital requirements ${ }^{34}$ and that no automatic consequences of the potential breach of this requirement are mentioned in the EU regime. ${ }^{35}$ Further, Tobias Tröger argued that MREL framework is too granular and complex to adequately price the risk underlying the MREL-eligible instruments and so, it should be separated from resolution strategies and drafted more like a capital layer. ${ }^{36}$

Lastly, the BRRD also suffered from the lack of credibility regarding possible resolution of systemic institutions. No one really believes, that a 'too big to fail' bank could be resolved without any form of bail-out. Concetta Brescia Morra claims that not enough discretion is granted to the resolution authorities. ${ }^{37} \mathrm{John}$ Armour and co-authors predict that resolution via sale of the business 'plus an element of bail-out is likely to be the EU pattern, should a large and complex financial institution ever enter resolution. ${ }^{38}$ Also lack of sufficient resources in the resolution fund undermines the case for BRRD-based resolution of systemic banks.

31 Tyler Davis, "Who's afraid of the big bad bail-in?”, Global Capital, 12 May 2016, https://www.globalcapital.com/article/xrmjj9n9mnyq/whos-afraid-of-the-big-badbail-in, accessed 10 June 2021.

32 For instance, whether BRRD should not have been adopted in the form of regulation. See Tom Young, "Editorial: Do we need a BRRR?", International Financial Law Review, 14 March 2016.

33 Concetta Brescia Morra, "The New European Union Framework for Banking Crisis Management: Rules versus Discretion," European Company and Financial Law Review $2019,349,353$.

$34 S R B$, List of public Q\&As on MREL, https://srb.europa.eu/sites/srbsite/files/list_of_ public_qas_on_mrel_-_clean.pdf, accessed 10 June 2021.

35 Julian Burkhard/Stefano Rosetto, "AT1 Coupon cancellation risk: consequences of MREL and TLAC breaches”, International Financial Law Review, 2 March 2015.

36 Tröger, JBR 2020, 64 (fn. 7).

37 Brescia Morra (fn. 33), 376.

38 John Armour/Dan Awrey/Paul Davies/Luca Enriques/Jeffrey N. Gordon/Colin Mayer/Jennifer Payne, Principles of Financial Regulation, 2016, p. 355. 


\subsection{Banking Reform Package as a Way Forward}

In light of these numerous shortcomings, EU regulators started working on the second version of the BRRD. However, it turned out that not only the $B R R D$ requires some revisions and updates. Most of the legal acts introduced post-crisis also needed refreshing. The final Banking Reform Package adopted in 2019 encompassed Capital Requirements Directive V (CRD V), ${ }^{39}$ Capital Requirements Regulation II (CRR II) ${ }^{40}$ update to Single Resolution Mechanism Regulation (SRMRII) ${ }^{41}$ and finally, the new version of Bank Recovery and Resolution Directive (BRRD II). ${ }^{42}$ Most significant changes introduced by the CRD V and the CRR II included adoption of new standardised approach for counterparty risk, implementation of predefined level of leverage ratio, as well as liquidity enhancing net stable funding ratio. ${ }^{43}$ Additionally, third-country financial groups shall establish an intermediate parent undertaking within the European Union. ${ }^{44}$

As for the resolution-related novelties, the revision was very wide-ranging - it covered most of the aspects addressed by the BRRD - from scope, definitions and competencies of resolution authorities, through preparatory activities and

39 Directive (EU) 2019/878 of the European Parliament and of the Council of 20 May 2019 amending Directive 2013/36/EU as regards exempted entities, financial holding companies, mixed financial holding companies, remuneration, supervisory measures and powers and capital conservation measures. We shall use the abbreviation CRDV in reference to the amended directive as a whole.

40 Regulation (EU) 2019/876 of the European Parliament and of the Council of 20 May 2019 amending Regulation (EU) 575/2013 as regards the leverage ratio, the net stable funding ratio, requirements for own funds and eligible liabilities, counterparty credit risk, market risk, exposures to central counterparties, exposures to collective investment undertakings, large exposures, reporting and disclosure requirements, and Regulation (EU) 648/2012. We shall use the abbreviation CRRII in reference to the amended regulation as a whole.

41 Regulation (EU) 2019/877 of the European Parliament and of the Council of 20 May 2019 amending Regulation (EU) 806/2014 as regards the loss-absorbing and recapitalisation capacity of credit institutions and investment firms. We shall use the abbreviation SRMRII in reference to the amended regulation as a whole.

42 Directive (EU) 2019/879 of the European Parliament and of the Council of 20 May 2019 amending Directive 2014/59/EU as regards the loss-absorbing and recapitalisation capacity of credit institutions and investment firms and Directive 98/26/EC.

43 For more details and a good overview of the changes see Mete Feridun, "The EU banking package: CRD V \& CRR II,” Regulation Y, 25.04.2019, https://regulation-y.com/ 2019/04/25/the-eu-banking-package-crd-v-crr-ii/, accessed 10 June 2021.

44 For an analysis of this requirement and potential consequences see Katarzyna Parchimowicz, "Missed targets and misplaced incentives? The case of parent undertaking requirement in the USA and in the EU”, Journal of Banking Regulation 21 (2020), 212. 
MREL to resolution of cross-border groups. The TLAC and MREL were streamlined by means of introduction of TLAC requirement via the CRR II and adjusting provisions on MREL in the BRRD. Also a new category of big banks was introduced - the so called 'top-tier banks', whose balance sheets exceeds 100EUR billion.

Most importantly for this paper, the CRR II and the BRRD II shed new light on the character of MREL requirement. Actually, what Tröger advocates about MREL structured more like a capital layer in separation from resolution context, could be slowly materializing in the legal framework of MREL. Already in the previous version of the BRRD, some signs indicated that MREL's role is actually reaching beyond the strictly resolution-related. Moreover, the new provisions on the quantity and quality of MREL instruments are included in the CRR II, the main legal act on prudential requirements. ${ }^{45}$ It looks like in case of this coin one side could be bigger than the other.

\section{Two faces of $M R E L$}

\subsection{In Resolution}

MREL has been originally linked to resolution and rightly so. The EU legislator embraced its resolution-related character by describing it in the BRRD, the legal act concentrated entirely on resolving financial institutions. Also, public Q\&As published by the SRB explains that MREL is 'to ensure an effective and credible application of the bail-in tool. Failure to meet MREL may negatively impact institutions' loss absorption and recapitalisation capacity and, ultimately, the overall effectiveness of resolution. This requirement is part of the necessary steps needed to make institutions resolvable. ${ }^{46}$ Such definition reflects the standard approach to MREL, only viewed as strictly functional to the implementation of resolution. Also, most resolution experts have shared this perspective. MREL - so the argument runs - is supposed to 'limit the risk of contagion or bank runs, when it comes to conversions and write-downs, ${ }^{47}$ and thus is clearly contingent on default. The essential character of MREL in the context of bail-in effectiveness is also stressed in the literature. As Wojcik stresses 'bail-in can only attain its objectives where a bank has sufficient own

45 Art. 72 a et seqq. CRRII.

$46 \operatorname{SRB},($ fn. 34), 1.

47 Simone Alvaro/Marco Lamandini/David Ramos Muñoz/Elena Ghibellini/Francesca Pellegrini, "The Marketing of MREL Securities after BRRD Interactions between Prudential and Transparency Requirements and the Challenges Which Lie Ahead”, CONSOB Legal Research Papers (Quaderni Giuridici) no. 15 (2017), 22. 
funds and eligible liabilities which can be effectively bailed-in in a resolution situation. ${ }^{38}$

The distinction between MREL and prudential requirements could also be derived from the conditions that ought to be fulfilled to trigger resolution. Namely, the first indicator of 'failing or likely to fail' status, the depletion of own funds, does not refer to MREL. Breach of MREL requirement itself, without infringement of the CRD requirements, could not lead to this assessment. However, it is worth noting that not all the infringement of prudential requirements leads to the designation of a bank as "failing or likely to fail". ${ }^{49}$

MREL's mere ex post nature, meaning its usefulness only after resolution is triggered, has been also underlined by the prescribed consequences that given institution must face in case of violation of this requirement. According to the original version of the BRRD, MREL breaches were not sanctioned by any legal prescription, institutions was supposed to be urged to restore it. Precisely, 'resolution authorities, in coordination with competent authorities, [were supposed to] require and verify that institutions meet the minimum requirement for own funds and eligible liabilities. ${ }^{50}$ Some scholars derived indirect consequences from the stacking order, namely the relation between MREL and combined buffer requirements. For instance, Tröger argues that unsuccessful issuance of MREL could lead to depletion of CET1, and thus trigger restrictions on payouts from article 141 of CRD IV. ${ }^{51}$ However, no provision directly prescribed such restrictions for the breach of MREL standard.

\subsection{Preventive}

On the other hand, it can be argued that MREL's preventive character has been noticeable from the very beginning. Indeed, already accusations of 'doubling capital requirements' could be perceived as granting MREL its preventive title. Even the SRB in its Q\&A referenced above, does not deny that it could be seen as yet another capital layer, it even calls it a separate minimum requirement. ${ }^{52}$

Regardless of the signs that holding MREL might be bearing some ex-ante effect, its preventive potential has so far failed to be recognised. It has been perceived mostly as putting additional burden on the credit institutions, or through the lens of market discipline potential. In contrast, we contend that MREL has

48 Wojcik (fn.1), 113.

49 Think, for instance of the preventive buffers, whose breach only implies possible limitation on distribution. This specific point is discussed at length in Section 4.

50 Art. 45 (15) BRRD.

51 Tröger, JBR 2020, 64 (fn. 7), 74.

$52 \operatorname{SRB}$ (fn. 34), 1. 
in its nature a preventive effect. Its impact goes much beyond compliance challenges that banks have to face, or the influence of bail-inable creditors on risktaking. The preventive potential of MREL should be perceived at both microand macroprudential level. As for the former, MREL determination framework and consequences of its breach would definitely influence individual bank's operations or even business models. In the context of the latter, MREL seems to complement prudential capital requirements and so to raise the resilience of the financial system in good times, achieving countercyclical objectives.

In line with our claim, the BRRD II (along with the CRR II) sets up a viable legal framework to operationalise such preventive nature. It seems to acknowledge MREL's ex-ante potential and not only at one level.

Firstly, the preventive influence of MREL is noticeable from the general and functional perspective. MREL for G-SIIs, along with MREL quality requirements, has been included in the CRR II, among the capital requirements of strictly preventive nature. Furthermore, also aspect of MREL's composition and counting of the CET 1 capital could indicate its similarity to the combined buffer requirements (CBR). ${ }^{53}$

Secondly, MREL's preventiveness has been vastly developed by the particular material provisions introduced in the BRRD II and the CRR II. First, the abovementioned determination of MREL both at qualitative and quantitative levels suggests its transformation into preventive requirement. Second and maybe most convincing in that regard is the BRRD II's formulation of consequences, should MREL be breached. It undoubtedly presents the broadest range of tools in the whole of EU banking law regime, mixing resolution-related powers with supervisory competences. It seems logical, that the EU regulators want to incentivise banks to maintain MREL at all times, as much as they should do with other capital minima and CBR. If they wanted MREL to be only resolution-connected tool, they would maintain the solution present in the US legal regime in the context of TLAC - its breach triggers distribution limitations only.

These two main areas where MREL slowly but steadily becomes more a preventive than a resolution-dependent requirement require in-depth analysis and assessment, starting from the relation between MREL and capital requirements, through the changes in its determination, to the broad scope of discretion granted to authorities in case MREL is breached.

Before delving deeper on the design of the new MREL framework, a methodological caveat is warranted. Our analysis demonstrates the existence of a preventive component of MREL across multiple dimensions: in MREL determination and enforcement, with effects on both micro- and macro-prudential 
policies. We also argue that such a preventive component positively complements the existing prudential framework.

However, we do not posit that the SRB and other resolution authorities shall always put their 'preventive hat' on and approach MREL from a preventive perspective. On the contrary, this is a problematic issue since the SRB probably even lacks a preventive mandate. Some of the issues related to the implementation of the preventive potential of MREL are discussed in Section 5.

\section{MREL after the Banking Reform Package}

\subsection{Capital Requirements and Eligible Liabilities}

The main goal of capital requirements is to safeguard the solvency of banks and foster their prudent and sound management. ${ }^{54}$ In so doing, the EU regulatory framework determines the level and quality of the capital banks must issue and hold. ${ }^{55}$

On the contrary, as discussed in Section 3, the main and initial policy goal of setting MREL is to have enough eligible liabilities to resolve a bank should it get failing or likely to fail ${ }^{56}$. In this view, meeting MREL in good times serves for maintaining the bank resolvable at all times ${ }^{57}$. To this end, the resolution authority (RA) determines the required level of eligible liabilities and, as a consequence, restricts the entrepreneurial freedom of banks to determine their funding strategy, requiring to issue a certain amount of long-term, non-runnable debt. ${ }^{58}$

Despite the difference in the primary policy goals pursued by the two sets of requirements; functionally, setting MREL does not differ much from regulating capital. Also in the case of capital requirements, banks must abide by a certain funding structure and follow the quantitative and qualitative requirements set by the the CRR and the CRD.

This functional resemblance suggests that MREL's effects go beyond bank resolvability and intersects prudential policies. The Banking Reform Package of

54 Recital 37 CRRII. See John Armour/Dan Awrey et al. (fn 38), chapter 14, p. 290.

55 For minimum capital requirements, see art. 92 CRRII; for Pillar 2 capital, see art. 104 CRDV; for the Combined Buffer Requirement see art. 128 CRDV.

56 See art. $45 \mathrm{c}(1)(\mathrm{a})$ and art. 32 BRRDII.

57 See art. 15 BRRDII. A bank is deemed to be resolvable: "it is feasible and credible for the resolution authority to either liquidate it under normal insolvency proceedings or to resolve it by applying the different resolution tools and powers to the institution while avoiding to the maximum extent possible any significant adverse effect on the financial system, including in circumstances of broader financial instability or system-wide events”.

58 On the qualitative characteristics of MREL instruments, see art. 72 b CRRII. 
July 2019 goes in the direction of recognizing MREL as a two-face Janus. On the one hand, it acknowledges its preventive nature, including the requirements for own funds and eligible liabilities in the CRRII ${ }^{59}$ as a complement of capital requirements, at least for G-SIIs. On the other hand, BRRRII confirms and details the nature of MREL as a requirement to guarantee the resolvability of the bank. ${ }^{60}$

Thus, the first step to evaluate the preventive potential of MREL is to assess its relationships with capital regulation in the current EU legal framework. In this perspective, it is important to differentiate between minima and buffers. Minimum capital requirements are the cornerstone of bank prudential regulation as of Basel I ${ }^{61}$ and are now set in the CRRII. ${ }^{62}$ These requirements shall be met at all times. Failing to meet those requirements can have severe consequences, up to the withdrawal of the banking licence. ${ }^{63}$ On the other hand, buffers are a new form of requirements introduced in the aftermath of the financial crisis with the aim of countering the procyclicality of capital regulation and the macro-economic externalities of banks' activities. ${ }^{64}$

Article 128(1)(6) CRDV introduces the combined buffer requirements (CBR), ${ }^{65}$ an add-on to minimum requirements that must be met with common equity. ${ }^{66}$ Differently from minimum requirements, buffers are designed to build excessive capital capacity in good time that can be depleted in bad times without endangering the solvency of the troubled institution. ${ }^{67}$ Accordingly,

59 See art. 92a CRRII.

60 Breaching MREL is explicitly defined as an impediment to resolvability, see art. $45 \mathrm{k}$ BRRDII.

61 BCBS, International convergence of capital measurement and capital standards, 1988.

62 Art. 92 CRRII: "institutions shall at all times satisfy the following own funds requirements: (a) a Common Equity Tier 1 capital ratio of 4,5\%; (b) a Tier 1 capital ratio of $6 \%$; (c) a total capital ratio of $8 \%$.".

63 Art. 18(1)(d) CRDV.

64 Luca Amorello, "Europe Goes 'Countercyclical': A Legal Assessment of the New Countercyclical Dimension of the CRR/CRD IV Package”, European Business Organization Law Review 17 (2016), 137, 145.

65 Art. 128(6) CRDV: “combined buffer requirement" means the total Common Equity Tier 1 capital required to meet the requirement for the capital conservation buffer extended by the following, as applicable: (a) an institution-specific countercyclical capital buffer; (b) a G-SII buffer; (c) an O-SII buffer; (d) a systemic risk buffer.

66 Only capital of the highest quality counts toward buffer requirements. On the contrary, Additional Tier 1 instruments and Tier 2 instruments cannot be counter toward capital buffers. On the qualitative requirements of AT1 and T2 instruments see, respectively, art. 51 and art. 62 CRRII.

67 In this regard, the current supervisory response to the COVID-19 situation represents a paradigmatic example of the buffers' role in the current regulatory architecture. See $E C B, \mathrm{FAQ}$ on $\mathrm{ECB}$ supervisory measures in reaction to the coronavirus, https:// 
the consequences of breaching the CBR are milder and aim at restoring the buffer once the turmoil is overcome. Specifically, banks breaching the combined buffer requirement are restricted in their voluntary distributions ${ }^{68}$ and must present a "capital conservation plan". ${ }^{69}$

This legal design is consistent with the macro-economic aim to consider the credit and financial cycle in regulating bank capital, ${ }^{70}$ imposing higher requirements in good time to reduce risk-shifting and excessive risk-taking incentive and relaxing those in bad times to alleviate the possible credit crunch. ${ }^{71}$ Building excessive capacity in good times and restricting distributions when the bank is still relatively far from insolvency represent a coherent policy response to the Minsky's theory of financial instability and endogenous creation of financial crises. ${ }^{72}$ In this view, financial crises result from imbalances that are driven by, but also feed by, an unsustainable economic expansion, which manifests itself in unusually rapid growth of credit and asset prices. ${ }^{73}$

A third layer of capital requirement is the so called "Pillar 2" capital. The competent authority can require individual banks, on a case-by-case basis, to hold capital to cover additional risks ${ }^{74}$, as a result of the annual evaluation process. ${ }^{75}$

The problematic aspect in coordinating a multilayer capital regulation rests in the stacking order of the various capital components. This aspect is almost ir-

www.bankingsupervision.europa.eu/press/pr/date/2020/html/ssm.pr200320_ FAQs a4ac38e3ef.en.html, accessed 10 June 2021.

68 Art. 141 CRDV.

69 Art. 142 CRDV.

70 Mathias Drehmann/Claudio Borio/Kostas Tsatsaronis, "Anchoring Countercyclical Capital Buffers: The Role of Credit Aggregates”, International Journal of Central Banking, 4 (2011), 189, 194.

71 Countercyclicality is even more powerful looking at individual buffers. However, the power to implements individual buffers rests with the NCAs, with all the problem associated with the defense of national champion and the sovereign banks doom-loop. On these aspects, see Emmanuel Farhi/Jean Tirole, "Deadly Embrace: Sovereign and Financial Balance Sheets Doom Loops”, The Review of Economic Studies 85 (2018), 1781, 1787. For an overview of the national policies on buffers, see ESRB, Overview of national macroprudential measures, https://www.esrb.europa.eu/national_policy/html/ index.en.html, accessed 10 June 2021.

72 Minsky (fn. 10), p. 8.

73 Claudio Borio, "Towards a Macroprudential Framework for Financial Supervision and Regulation?”, CESifo Economic Studies 49 (2003), 181, 191.

74 Art. 104 a CRDV disciplines Pillar 2 Requirements. Art. 104b CRDV regulates Pillar 2 Guidance.

75 Supervisory Review and Evaluation Process (SREP), disciplined in art. 97 CRDV. For greater details see $E B A, 2018$ Guidelines on the revised common procedures and methodologies for the supervisory review and evaluation process (SREP) and supervisory stress testing, 19 July 2018. 
relevant in good times for a well-capitalised bank but becomes extremely relevant when the situation starts to deteriorate. The ways the various components are stacked changes the threshold for breaching the CBR and, hence, trigger the limitation on distributions. Clearly, minimum requirements are the first to be complied with. Then, the CRDV specifies that Pillar 2 requirements sit on top regulatory minima ${ }^{76}$. Finally, the CBR sits on top of the Pillar 2 capital. Therefore, the limitation on distributions can be triggered early and this has itself a positive macro-prudential effect as it restrains excessive distributions in a phase where capital needs to be strengthened without issuing fresh equity, as it might send negative signals to the market ${ }^{77}$.

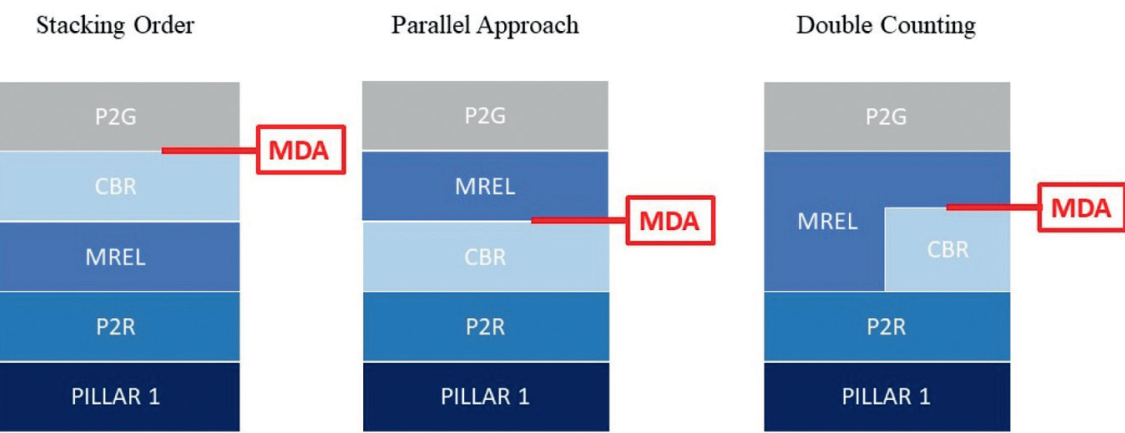

Figure 1: Different option in stacking Capital Requirements, Capital Buffers and MREL. (Scale not meaningful, just illustrative).

In this already complex conundrum, ${ }^{78}$ the position of MREL represents an additional problem to consider. Both own funds (i.e.: capital instruments) ${ }^{79}$ and

76 Art. 129(5) CRDV: "Institutions shall not use Common Equity Tier 1 capital that is maintained to meet the requirement under paragraph 1 of this Article to meet any requirements imposed under Article 104.”

77 Stewart Myers/Nicholas Majluf, "Corporate Financing and Investment Decisions When Firms Have Information That Investors Do Not Have”, Journal of Financial Economics 13 (1984), 187, 209.

78 The story becomes even more entangled by the differentiation between Pillar 2 Guidance and Pillar 2 Requirements, where only the latter is mandatory and counts for breaching the combined buffer requirement. Such differentiation was first introduced by the EBA SREP Guidelines of 2018 and then entered in primary law with the 2019 Banking Reform Package. On the problem from which this differentiation originated, see Paul Glasserman/Enrico Perotti, The Unconvertible CoCo Bonds, in: Douglas Evanoff/Geroge Kaufman/Agnese Leonelle/Simone Manganelli (eds.), Achieving Financial Stability: Challenges to Prudential Regulation, World Scientific, 2017, vol. 61, p. 317-325.

79 Art. 72 CRRII. 
other eligible liabilities ${ }^{80}$ constitute MREL. Therefore, it may arise the question of how to count CET1 instruments in excess of minimum requirements and Pillar 2 requirements. There are three possibilities, as graphically depicted in Figure 1. First, common equity in excess should first cover the MREL shortfall and, in turn, increase the amount of capital needed to comply with the $\mathrm{CBR}$. Second, it should cover the CBR without triggering the limitations on distribution. In this case, a breach of MREL requirement is likely to materialise. Third, common equity in excess counts for both MREL and CBR (double counting)..$^{81}$

The European legislator solved this conundrum adopting a compromise in between the first two regulatory options. The solution adopted by the BRRDII in this regard will be widely discussed in Section 4.3 , as it directly pertains to MREL breaches.

Interestingly, among these three possibilities, only the third one would be consistent with a mere ex-post approach to MREL, where the amount of eligible liabilities held by the institution is only relevant for the purpose of performing a resolution should the bank be declared "Failing or Likely to Fail". Interestingly, the double counting was the only option ruled out since the very beginning of the negotiation towards the BRRDII. ${ }^{82}$ This demonstrates, once again, that the double nature of MREL is inherent to its nature and, willingly or unwillingly, is also embraced by the European Legislator. Therefore, the prudential potential constitutes an important component of the MREL framework. The rest of this article discusses whether the legal framework resulting from the 2019 Banking Reform Package already fully exploit such a (macro)preventive potential.

Before moving forward and specifically discuss the MREL framework, it is important to stress once again that MREL regulation is not functionally different from capital regulation. It restrains the funding options of banks, regulating (part of) the composition of the liability side of their balance sheet. The regulatory framework on capital and the one on eligible liabilities are inherently integrated and their preventive effectiveness significantly depends on the quality of such integration.

Bearing in mind this take away point, the proceeding of the section discussed in detail the two crucial aspects of MREL determination (Section 4.2) and MREL breaches (Section 4.3) and highlights their prudential component.

80 See artt. 72a CRRII and 44 BRRDII.

$81 E B A$, Final Report on MREL - Report On The Implementation And Design Of The MREL Framework, 14 December 2016, p. 85.

82 Ibid., p. 86. In contrast, double-counting represented the dominant strategy employed by the SRB for MREL determination before the 2019 Reform Package. See EBA, Quantitative Report on MREL, 17 February 2020, p. 22. 


\subsection{MREL Determination}

The determination of MREL represents the first feature dense of preventive potential. Two aspects are crucial: the qualitative requirements to be counted as eligible liability and the rules to determine the quantitative level of MREL.

The Banking Reform Package innovates significantly on the qualitative requirements in two main directions. First, it introduces the structural subordination requirement: eligible liabilities must be subordinated to any other noneligible liability. ${ }^{83}$ This clearly goes in the direction of making banks more resolvable, smoothening the relationship between the resolution framework and national insolvency laws. ${ }^{84}$

Furthermore, the qualitative requirements for financial instruments to count toward MREL were also updated. Such an update goes in the direction of making MREL requirements more aligned with the qualitative requirements for capital instruments. ${ }^{85}$ In particular, the new regulation forecloses the possibility to include many of the standard debt covenants on eligible liabilities. For instance, the contractual arrangements governing the instruments cannot include any provision incentivising an early call or redemption of the instruments $;{ }^{86}$ or provisions to speed up the repayment for conditions other than insolvency or liquidation. ${ }^{87}$

These qualitative requirements parallel the requirements that were previously applied only to capital instruments ${ }^{88}$. In contrast, the first version of the BRRD established very light qualitative requirements mainly focusing on the requirements of having at least one year of residual maturity. ${ }^{89}$ These closely re-

83 Art. 72b(2)(d) CRRII. The subordination requirement knows few exceptions discussed in art. 72c CRRII.

84 Lynette Janssen, "Bail-In from an Insolvency Law Perspective", Norton Journal of Bankruptcy Law and Practice 26 (2017), 457. For a general overview of the matter, see European Commission, Study on the differences between bank insolvency laws and on their potential harmonisation. Final Report, 2019, https://ec.europa.eu/info/sites/info/ files/business_economy_euro/banking_and_finance/documents/191106-study-bankinsolvency_en.pdf; accessed 10 June 2021.

85 Art. $72 \mathrm{~b}(2)(\mathrm{g}-\mathrm{m})$ CRRII.

86 Art. $72 \mathrm{~b}(2)(\mathrm{g})$ CRRII.

87 Art. $72 \mathrm{~b}(2)(\mathrm{k})$ CRRII.

88 See the parallel between the requirements of art. 72b CRRII for MREL instruments and art. 63 CRRII for Tier 2 Instruments.

89 The original version of the BRRD, in art. 45(4) provided that: "Eligible liabilities shall be included in the amount of own funds and eligible liabilities referred to in paragraph 1 only if they satisfy the following conditions: (a) the instrument is issued and fully paid up; (b) the liability is not owed to, secured by or guaranteed by the institution itself; (c) 
sembled the criteria to consider a liability as bail-inable in resolution ${ }^{90}$ and departed significantly from the qualitative requirements for capital instruments.

This transition has a profound functional meaning. It implicitly says that MREL instruments are not only functional to perform a bail-in should the bank enter in resolution, but these also serves the maintenance of the safety and soundness of the institution in good time, such as the (preventive) capital requirements. ${ }^{91}$

These provisions, at a first sight, might appear as a very technical and legalistic set of specifications. However, these make a remarkable functional difference also for the ability of creditors to discipline the bank. The corporate finance literature has recognised the nature of debt contracts as a way to contingently allocate control over corporate activities, shifting it from shareholders to creditors. $^{92}$ The main statutory contingency in non-financial institution is insolvency. But contractual agreements, covenants, can determine partial control shifts also when the borrower is solvent in order to minimise the agency costs of debt. ${ }^{93}$ On the other hand, allowing for financial covenants implies a likely fund outflow when the situation of the bank starts deteriorating. ${ }^{94}$ This would, consequently, pose issues of financial stability.

Complementing these provisions on the stipulation of the contract, the CRR disciplined a crucial aspect of its executions. The new provisions resemble qua-

the purchase of the instrument was not funded directly or indirectly by the institution; (d) the liability has a remaining maturity of at least one year".

90 Not all the liabilities that are bail-inable in resolution counts toward MREL. For what is here of interests, liabilities with remaining maturity of 7 days are, in general, considered bail-inable but these do not count toward MREL unless they have 1 year of residual maturity.

91 Eligible liabilities shall comply with those qualitative requirements despite their issuer. Art. 72 b CRR directly applies to liabilities issued by G-SIIs, but art. 45b(1)(b) BRRDII recalls the requirements of art. 72b CRRII in the general discipline of eligible liabilities. Therefore, these qualitative requirements have general application for all the resolution entities.

92 Philippe Aghion/Patrick Bolton, "An Incomplete Contracts Approach to Financial Contracting”, The Review of Economic Studies 59 (1992), 473, 485. These authors built their argument on the seminal study by Sanford Grossman/Oliver D. Hart, "The Costs and Benefits of Ownership: A Theory of Vertical and Lateral Integration, Journal of Political Economy 94 (1986), 691.

93 Greg Nini/David Smith/Amir Sufi, "Creditor Control Rights, Corporate Governance, and Firm Value", The Review of Financial Studies 25 (2012), 1713, 1731 et seqq.; Michael Bradley/Michael Roberts, "The Structure and Pricing of Corporate Debt Covenants”, The Quarterly Journal of Finance 5 (2015), 1550001.

94 On the possibility of imposing covenants in the banking industry see Mark Flannery, "Debt Maturity and the Deadweight Cost of Leverage: Optimally Financing Banking Firms”, The American Economic Review 84 (1994), 320, 326. 
litative requirements for capital instruments also in relation to calling, redeeming or repurchasing instruments. Such activities are now subject to stringent conditions and to the prior approval of the competent authority. ${ }^{95}$

Therefore, the functional relevance of reforming qualitative requirements for eligible liabilities lies in striking a balance between financial stability considerations and market discipline. ${ }^{96}$ After the Banking Reform Package, the financial stability considerations prevailed not only when it comes to capital instruments but also for other eligible liabilities. As a by-product of this new approach, the regulatory and supervisory agencies gained the upper end over the market participants in making the MREL framework effective ex-ante. This is consistent with the approach to banking regulation according to which market discipline cannot work because of the special features of banks; hence, the supervisor should substitute the market participants, mimicking the behaviours these would have had in normal market conditions. ${ }^{97}$

Building on this last observation, the rules for the quantitative determination of MREL represent a further step toward its preventive understanding. In the first version of the BRRD, the RA determined the MREL on a case-by-case basis. ${ }^{98}$ In contrast, the BRRDII states that MREL ought to be met at all times, such as minimum capital requirements, and that the determination of MREL must be expressed as a percentage of both the risk-weighted and non-riskweighted exposures of each institution..$^{99}$

This second aspects represents an important innovation compared to the previous regime, insofar as imposing a plain leverage ratio as a complement of the traditional risk-weighted ratio better capture the leverage dynamics over the financial cycle. This approach constitutes a cornerstone of the post-crisis countercyclical (preventive) financial regulation. ${ }^{100}$ A leverage ratio requirement was already in place for own funds in the first version of the

95 Art. 77(2) CRRII and 78a CRRII.

96 Edoardo Martino, "Bail-Inable Securities and Financial Contracting: Can Contracts Discipline Bankers?”, European Journal of Risk Regulation 10 (2019), 164, 179.

97 The so-called Representation Hypothesis of Banking Regulation and Supervision. See Dewatripont Mathias/Jean Tirole, The Prudential Regulation of Banks, 1994, vol. 1. On the inability of bank creditors to price correctly their instruments, see the seminal work by Douglas Diamond/Philip Dybvig, "Bank Runs, Deposit Insurance, and Liquidity”, Journal of Political Economy 91 (1983), 401.

98 Art. 45 BRRD. See also EBA, Regulatory Technical Standards on criteria for determining the minimum requirement for own funds and eligible liabilities under Directive 2014/59/EU, 2015.

99 Art. 45 (1) and (2) BRRD.

100 Angelo Baglioni/Elena Beccalli/Andrea Boitani/Andrea Monticini, "Is the leverage of European banks procyclical?”, Empirical Economics 45(3) (2013), 1251. 
$\mathrm{CRR}^{101}$. Again, the alignment with capital requirements testifies a new understanding of the preventive potential of the MREL framework.

The specific determination depends upon the systemic relevance of each bank. Nonetheless, article 45c(1) BRRDII sets down some general principles that should guide the resolution authority in the quantitative determination of MREL. First of all, each institution should have sufficient eligible liabilities to implement the preferred resolution strategy envisaged in the resolution plan. ${ }^{102}$ This principle clearly looks at assuring the resolvability of the institution and is in line with the main-stream characterisation of MREL. Besides assuring the resolvability of the institutions, the RA must also consider the "size, the business model, the funding model and the risk profile" of the institutions. ${ }^{103}$ The RA shall also mind the negative spillovers on financial stability that the failure of an institution may have, with specific regard to counterparty risk. ${ }^{104}$

Reading together these last two provisions clearly shows that - in determining MREL quantity - the resolution authority can, and should, go beyond resolvability consideration. The RA should consider the specific risks posed by each institution, trying to prevent these from failing. Furthermore, the reference of the interconnectedness of counterparties as a criterion for MREL determination trespasses the border of micro-prudential policy and enters directly into the macro-prudential area. Such a reference allows to set MREL considering the cross-sectional contribution to systemic risk posed by each institution. ${ }^{105}$

The case-by-case determination that characterised the first version of the BRRD is now only applied to less significant institutions. ${ }^{106}$ Those should be required to hold enough eligible instruments to cover the expected losses and to appropriately recapitalise the bank after resolution. In this instance, the re-

101 Art. 429 CRRII.

102 Art. $45 \mathrm{c}(1)(\mathrm{a}-\mathrm{c})$ BRRDII.

103 Art. 45c(1) (d) BRRD II.

104 Art. 45c(1) (e) BRRDII. This provision can be considered the ex-ante complement of the ad hoc exemption powers granted to the RA by art. 44(3). On the bail-in and counterparty risk see Wolf-Georg Ringe/Jatine Patel, “The Dark Side of Bank Resolution: Counterparty Risk through Bail-In”, European Banking Institute Working Papers 31 (2019), 9; Benjamin Bernard/Agostino Capponi/Joseph Stiglitz, "Bail-Ins and BailOuts: Incentives, Connectivity, and Systemic Stability”, National Bureau of Economic Research 23747 (2017), 32.

105 John Armour/Dan Awrey et al. (fn. 38), chapter 19, p. 410. More specifically on network sensitive calibration, see Luca Enriques/Alessandro Romano/Thom Wetzer, “Network-Sensitive Financial Regulation”, The Journal of Corporation Law 2020, 351,368 .

106 European banks with less than 100 billion EUR in assets, see art. 45c(5) BRRDII. 
solution authority has little room for considering preventive aspects in determining the level of MREL. ${ }^{107}$ For "top-tier" European banks that do not qualify as G-SIIs, the case-by-case determination only partially applies. The BRRDII set a regulatory floor to the level of own funds and eligible liability, that must be at least $13,5 \%$ of risk weighted exposures and $5 \%$ of non-risk weighted exposure. ${ }^{108}$ Such a floor can, in itself, be considered countercyclical. Even if in good times the level of expected losses is particularly low because of the economic condition, the MREL cannot fall below the predetermined amount, limiting leverage and risk-shifting. Finally, the requirement for globally systemic banks is fully harmonised to the TLAC standard. Therefore, GSII banks shall hold $18,0 \%$ of risk weighted exposures and $6,75 \%$ of non-risk weighted exposure ${ }^{109}$. Notably, the introduction of different categories of banks proves the awareness of the EU legislator about the macro-prudential effects of MREL determination and reinforces the argument proposed in this article.

In addition, the level of required MREL can be further increased if the RA deems it necessary to fulfil the general conditions of article $45 c$, ${ }^{110}$ i.e.: assuring the resolvability of the institution and, crucially for this paper, considering the specificities of each institution and the specific systemic risks its failure would pose. ${ }^{111}$

In the jargon resulting from the Banking Reform Package, this was referred as Pillar 2 MREL, considering it in parallel with Pillar 2 capital requirements. ${ }^{112}$ However, such reference is incorrect. This additional layer of MREL lack some of the prerequisites of Pillar 2 capital. According to the CRD, the competent authority can require to hold own fund in excess ${ }^{113}$ mainly to "ensure a sound management and coverage of [banks'] risks" 114 if the outcome of the annual review process reveals that those are not sufficiently accounted for by regulatory requirement.

Article 45d (3) refers to the general principles of MREL determination, i.e.: ensuring resolvability, considering the business model and risk-profile of the

107 Partially, the RA can take a preventive approach to less-significant bank after a resolution has happened by increasing the recapitalization component of MREL to ensure market confidence after resolution. See art. $45 \mathrm{c}(3)$ sixth subparagraph BRRDII.

108 Art. 45c(5) BRRDII.

109 Art. 92 a CRRII.

110 Art. $45 \mathrm{~d}(1)(\mathrm{b})$ and $45 \mathrm{~d}(3)$ BRRDII.

111 Art. 46d (1)(b) BRRDII.

112 See for instance, $A F M E$, Resolution aspects of the EU Risk Reduction Measures Package, October 2018, https://www.afme.eu/portals/O/globalassets/downloads/publications/ afme-rrn-resolution-aspects-of-the-eu-rrm-package.pdf, accessed 10 June 2021.

113 Art. 104(1)(a) and 104a CRDV.

114 Art. 97(3) CRDV. 
bank and the systemic concerns it poses. Ensuring resolvability is a resolution specific principle. However, the other two are conceptually closer to capital buffers than to Pillar 2 capital. Contrarily to capital buffers, the additional amount of eligible instruments required pursuing article $45 \mathrm{~d}(3)$ is structurally part of MREL and, accordingly, shall be met at all time. Hence, its legal design differs sharply from buffers.

This ambiguity in the legal nature of MREL dates back to its first formulation and closely relates to the regime on the enforcement of MREL breaches. In the first version of the BRRD, the RA had no enforcement mechanisms to handle a potential breach. This is clearly at odds with the legal determination of MREL as a requirement to be met at all times. The European Legislator tackled this gap in the BRRDII, providing the RA with intrusive powers to enforce MREL. Nonetheless, some ambiguity in the design of the rules and the remedies still persists, signalling that the understanding of the legal and functional nature of MREL is not yet perfect.

\subsection{MREL Breaches}

The new enforcement powers in case of an MREL breach constitute the most innovative aspect of the MREL framework in the BRRDII. Regulatory enforcement represents a quintessential element to make preventive regulation effective and efficient: "The enforcement of regulation and government controls is complex and to a large extent determines the effects of the law. Yet it is surprising how many discussions of government regulation implicitly assume that laws are somehow self-enforcing and that there is full compliance". ${ }^{15}$ This was largely the case in the first version of the BRRD, where the resolution authority lacked clearly defined and proportionate legal tools to preventively address a breach of MREL. ${ }^{116}$

The Banking Reform Package tried to solve this shortcoming by granting the RA with extensive powers to address any breach of MREL requirements. ${ }^{117}$ In so doing, the resolution authority can implement the powers to remove impediments to resolvability; ${ }^{118}$ restrict certain distributions; ${ }^{119}$ impose one of the Pillar 2 measures attributed to the competent authority; ${ }^{120}$ use the early inter-

115 Paul Fenn/Cento Veljanovski, "A Positive Economic Theory of Regulatory Enforcement”, The Economic Journal 98 (1988), 1055, 1055.

116 EBA, Final Report on MREL (fn. 81), p. 94.

117 Art. 45k BRRDII.

118 Art. 17 and 18 BRRDII.

119 Art. 16a BRRDII.

120 Art. 104 CRDV. 
vention powers provided by the BRRD; ${ }^{121}$ impose monetary sanctions and other administrative measures. ${ }^{122}$

From a legal perspective, it seems that these powers should be interpreted as strictly tied to the goal of addressing MREL breaches. So, for instance, breaching MREL does not automatically trigger the early intervention phase but the resolution authority can use those powers to address a breach. Furthermore, breaching MREL can be qualified as a material impediment to resolvability ${ }^{123}$ for which the law provides wider enforcement powers as compared to other impediments to resolvability.

The imposition of penalties, though legally relevant, does not seem to have a substantive ex-ante potential. The vast literature on law enforcement highlights how the two crucial components to determine the effectiveness of a sanction are its magnitude and the probability of detection. ${ }^{124}$ In the context of banking, optimizing the deterrence level of penalties would likely mean to increase the magnitude of the sanction to a point that would, itself, endanger the stability of the institution. Therefore, behavioural remedies seem to better fit the case of MREL breaches and can be complemented, if necessary, by the sanctions provided by Articles 110 and 111 of the BRRD. The use of early intervention powers does not seem to have great ex-ante potential. It is only worth mentioning that it allows for an early trigger of the recovery plan. ${ }^{125}$ The recovery play may encompass planned measures to reduce risk and leverage or restructure liabilities, so that the preventive effect can be indirect. ${ }^{126}$

The other three sets of powers are crucial to deeply understand the ex-ante nature and the preventive potential of MREL. Hence, these deserve a detailed discussion. First, the RA can use the power to remove impediments to resolvability. The resolvability assessment consists in a state of the art, periodical exercise during which the resolution authority assesses whether the preferred resolution strategy, as envisaged in the resolution plan, is credible and feasible. ${ }^{127}$ Breaching MREL constitutes a material impediment to resolvability and, consequently, the resolution authority can certainly use the powers for removing such impediments. ${ }^{128}$

121 Art. 27 BRRDII.

122 Art. 110 and 111 BRRDII.

123 Art. 17(3) BRRDII.

124 See, for instance, Gary Becker, "Crime and Punishment: An Economic Approach", Journal of Political Economy 76 (1968), 169, 206.

125 Art. 27(1) BRRDII.

126 See Annex A to BRRDII, points (12) and (13).

127 Art. 15(1) third subparagraph, BRRDII.

128 Removing impediments to resolvability entails a quite complex and time-consuming procedure. The removal of substantive impediments benefits from an expedite procedure, see art. 17(3) BRRDII. 
Before discussing the specific powers to remove impediments to resolvability, it is worth noting how the BRRD itself recognises the ex-ante and potentially macro-prudential impact of those powers. In identifying the suitable power, the resolution authority must "duly consider the potential effect of those measures on the particular entity, on the internal market for financial services, and on the financial stability in other Member States and in the Union as a whole". ${ }^{129}$ This formulation seems to hint at the possible adverse consequences of removing the impediments to resolvability. However, as this paper have argued, this may also be interpreted with a positive connotation: between two equally effective measure to remove impediments to resolvability, chose the one that has also a preventive, micro- or macro-prudential, effect.

The powers aiming at removing impediments to resolvability can be split into MREL-specific and other general powers. Among the MREL-specific powers, the resolution authority can ask the bank to issue new eligible liabilities ${ }^{130}$ and to renegotiate the contractual terms and the maturity profile of existing ones. ${ }^{131}$ Moreover, the RA can require to submit a plan to restore compliance with MREL, ${ }^{132}$ as a complement to other measures imposed to the bank or agreed upon during the informal phase. ${ }^{133}$ Among the non-MREL-specific powers, the resolution authority can require drawing or updating the intragroup financing arrangements; require the entity to limit its exposures; divest specific assets; limit or cease complex and risky activities or products; require to change the legal or operational structure. ${ }^{134}$

Looking at the formulation of the law and the current EBA Guidelines on the matter, it seems that the resolution authority has full discretion in choosing the measure to address the impediment, so long as the measure is proportionate and the decision is justified. ${ }^{135}$ Therefore, the resolution authority should not be restricted to the MREL-specific measures but could use whole menu of powers. ${ }^{136}$

The resolvability assessment clearly showcases the double nature of MREL. On the one hand, its first goal is to make resolution credible and fea-

129 Art. 17(7) BRRDII.

130 Art. 17(5)(i) BRRDII.

131 Art. 17(5)(j) and (ja) BRRDII.

132 Art. 17(5)(ha) BRRDII analogous to a capital restoration plan under art. 104(1)(c) of the CRDV.

133 Art. 17(3) BRRDII.

134 Art. 17(5), let (a)-(g) BRRDII.

135 Art. 17(6) BRRDII.

$136 E B A$, Guidelines on the specification of measures to reduce or remove impediments to resolvability and the circumstances in which each measure may be applied under Directive 2014/59/EU, 19 December 2014. The current guidelines do not consider the novelties in BRRD2. 
sible; hence, looking at the ex-post nature of MREL. However, this has two preventive spill-overs. First, making resolution as credible as possible increases the level of market discipline ex-ante. Second, the powers to address the impediments to resolvability shape banking activities and funding model ex-ante in the direction of increasing bank resilience. This latter observation is particularly important when positioned over the financial cycle. As the EBA Guidelines point out: "Resolution authorities may apply the measures solely to address impediments to resolvability without any existing breach or likely breach of prudential regulation requirements by the institution being required". ${ }^{137}$

This means that the powers for removing impediments to resolvability can be used timely, when the bank is still solvent and profitable, limiting the build-up of systemic risk in good time well before such risk materialises. At that point, when the situation starts deteriorating also other, more intrusive, measures can be used. However, from a preventive perspective, it is already too late.

The new power to limit certain distributions in relation to MREL or CBR breach fits in this framework of early policing of non-sustainable practices. The resolution authority has the power to prohibit the voluntary distributions exceeding the Maximum Distributable Amount related to the minimum requirement for own funds and eligible liabilities ('M-MDA'). ${ }^{138}$ The BRRDII provides two legal bases for the resolution authority to restrict distributions. The first, as discussed in Section 4.1, is the case when the bank is breaching the CBR when MREL is counted on top of Pillar 2 capital. The second case is to address MREL breaches. Article 16a describes the first case, linking the restriction on distributions to CBR breaches. In contrast, article 45k empowers the resolution authority to use this power also in case of MREL breaches, regardless of the bank's compliance with the CBR. This interpretation is important from a functional standpoint - it enlarges the scope of the power of the resolution authority and enhances its ability to tackle cases of early risk building.

The last relevant set of powers to address MREL breaches consists of the possibility to resort to the supervisory measure referred to in article 104 $\mathrm{CRD}$. Those are the solutions allowing the supervisor to take early actions as a result of the evaluation process ${ }^{139}$ or if the bank is likely to breach regulatory requirement in the following 12 months. ${ }^{140}$ The BRRDII allows to use these powers earlier, when capital requirements are complied with but MREL is not. The formulation of article 45k BRRDII suggests that the competent authority

137 Ibid., para 4 (b).

138 Dividends to shareholders, discretionary coupons to AT1 Coco holders, and variable remuneration to managers. See art. 16a(1), let (a),(b) and (c) BRRDII.

139 Art. 97(4) CRDV.

140 Art. 102(1)(b) CRDV. 
is the only one entitled to use those powers. The interpretation of the rule seems to suggest that supervisory measures can be triggered not only by the likelihood to breach capital requirements, but also by MREL breaches. In this case, the competent and resolution authorities must coordinate so that the competent authority uses its powers upon requests of the resolution authority. The coordination and overlaps in the powers and the mandates of the relevant authorities involved represents one of the most problematic aspects of the entire framework, as will be detailed in Section 5 .

\section{Assessment}

The analysis carried out so far unambiguously shows that the framework on own funds and eligible liabilities has a double nature. On the one hand, it is designed to allow the resolution of distressed banks ex post; on the other hand, it impacts the behaviours of banks ex-ante.

Traditionally, the analysis of the ex-ante effects of MREL, and more in general of the resolution framework, has been narrow and pre-eminently looked at its alleged impact on market discipline. ${ }^{141}$ Such a direct impact on market participants has been widely criticised both in the legal and economic scholarship, arguing that the system is too complex and not credible. ${ }^{142}$ Against this backdrop, our analysis demonstrated that the ex-ante effect of the BRRD, and of the MREL framework in particular, does not only reside on influencing market participants but also on the impact it has on banks' regulatory oversight. In this vein, the BRRDII strengthened the ex-ante regulatory potentials of MREL in many directions, as widely discussed in Section 4.

Many questions still remain open. What does this 'strengthened ex-ante approach' to MREL actually adds to prudential regulation? Is this additional layer of regulation efficient and effective? This debate is still far from being settled and only a careful scrutiny of the future behaviour of the Authorities will be able to shed additional light on the matter.

141 Tröger, JFR 2018 (fn. 7), 35; Edoardo Martino, “The Bail-In Beyond Unpredictability: Creditors' Incentives and Market Discipline”, European Business Organization Law Review 21 (2020), 789, 815.

142 Emilios Avgouleas/Charles Goodhart, "Critical Reflections on Bank Bail-Ins", Journal of Financial Regulation 1 (2015), 3. From an economic perspective, see Magdalena Ignatowski/Joseph Korte, "Resolution threats and bank discipline: What Europe can learn for the Single Resolution Mechanism from US experience", SAFE Policy Letter 33 (2014). 
To substantiate our claim, consider a simplified example: Bank A complies with capital requirements, including MREL. The bank's strategy is to comply with regulatory requirements, including MREL, largely with Common Equity. During an economic boom, Bank A quickly expands its operations and engages in risky bets. Specifically, the bank sets an over-the-counter clearing processes for non-standardised derivative instruments, together with other systemically significant banks. The expansion is funded through short-term secured debt, mainly repos, as it represents a very cheap source of funding in a period of economic growth. The bank calculates credit risk according to internal risk models. As a result, the risky bets result in a modest increase of riskweighted assets, so that the bank still complies with capital requirement, including the plain leverage ratio. However, the bank is now barely compliant with the required risk-weighted level for MREL, breaches the CBR, if MREL is calculated on top of Pillar 2 Requirements, and breaches the non-riskweighted MREL.

Before the 2019 Reform Package, the situation described in the example would have passed the supervisory scrutiny in good time, whereas specific action could have been taken only upon the deterioration of the economic situation, once risky activities were already undertaken. In contrast, the MREL specific provisions discussed in the previous section allow to tackle the excessive risktaking early on along several grounds. First, the power to restrict distribution pursuing Art. 16a BRRDII would be immediately available as the CBR calculated with the stacking order approach would already have been breached. Second, the Resolution Authority should consider the increased interconnectedness between Bank A and the other parties of the OTC derivatives and charge a quantitative addition in MREL, in the form of Pillar 2 MREL. Third, the breach of the non-risk-weighted MREL triggers the enforcement powers to address an MREL breach, including all the powers of Article 104 CRDV and, for instance, the possibility to require the issuance of new eligible instruments.

Based on the example, some general reflection can already be advanced with regard to the (potentially positive) additions that the new MREL framework will bring about for preventive regulation and supervision. First of all, the powers related to both MREL determination and breaches allow to address excessive risk-taking early on, often earlier than it would be possible for the supervisor as a result of SREP.

Second, the new qualitative requirements for MREL instruments as well as the wide enforcement powers for addressing MREL breaches strengthen the resilience of individual banks.

Third, the rules on MREL determination allow, at least in theory, to tailor MREL on the discrete impact of each individual bank on systemic risk. For instance, in quantifying Pillar 2 MREL and the market confidence buffer, the 
resolution authority ought to consider the impact of its decision on financial stability. ${ }^{143}$ Notably, within the Banking Union, MREL may represent a powerful countercyclical tool. The competence to implement capital buffers that are supposed to serve macro-prudential and countercyclical purposes rests with the National Competent Authority and not with the SSM. The first years of application already highlighted how national supervisors are extremely careful, if not reluctant, to impose additional requirements on national banks. In contrast, within the Banking Union, MREL is determined centrally by the SRB, which may be immune from the perverse incentives of national authorities in favouring national champions, especially in times of economic expansion. ${ }^{144}$

Finally, the new MREL framework, especially the enforcement powers, should enhance the banks resolvability and, in turn should make resolution ex-ante more credible. To steer clear of misunderstanding, this effect is likely to be marginal and unable to turn a non-credible resolution into a credible one. However, it may improve the credibility of resolution at the margin, by reducing its complexity and unpredictability. ${ }^{145}$ For instance, limiting distributions in case of an MREL breach implies the allocation of banks' losses to insiders, by reducing the contractually-agreed creditors' coupon. This would clearly signal the market that the resolution authority is able and willing to impose losses on bail-inable creditors, enhancing the credibility of a future resolution. ${ }^{146}$ Similarly, the new enforcement powers could enhance incentives behind resolvability assessment. So far, as recent studies show, ${ }^{147}$ no impediments have been notified, which seems clearly illogical, given the low overall credibility of the resolution framework. These new MREL-related powers could motivate resolution authorities to be more active in general, consequently further enhancing trust in the resolution system as a whole.

Despite the unveiled preventive potential, several pitfalls may prevent the new MREL framework from working efficiently and effectively. Within the Bank-

143 Art. 45c(1)(e) BRRDII.

144 Farbi/Tirole, (fn. 71), 1734.

145 Note that overcomplexity and unpredictability are the two elements preventing resolution to work according to Tröger, JFR 2018 (fn. 7), 35.

146 In contrast to what happened for Contingent Convertible instruments, where the competent authority signaled its reluctance toward both conversion and coupon skipping, signaling the market that the probability of bearing losses in going concern was extremely low. See Glasserman/Perotti (fn. 78), p. 325

147 Willem Pieter De Groen, "Impediments to resolvability of banks? What is the status quo?,” analysis for European Parliament, December 2019, https://www.europarl. europa.eu/RegData/etudes/IDAN/2019/634358/IPOL_IDA(2019)634358_EN.pdf, accessed 10 June 2021. 
ing Union, these flaws mainly relate to the complex multi-layered institutional structure of banking resolution and supervision.

First, the analysis reveals that an efficient application of the new framework will require considerable coordination and cooperation between the resolution and competent authorities. This goal appears far-reaching, at least within the Banking Union where the coordination and cooperation between the SRB and the ECB is still at an embryonic level. ${ }^{148}$ Potential clashes seem inevitable. Coordination problems constitute an inherent element of every interagency interaction. In the current EU banking system we can observe many instances proving said point. For example, the assessment of group recovery plan is made by the group-level supervisor and supervisors of subsidiaries, after consulting supervisory colleges and supervisors of significant branches, ${ }^{149}$ as noted by the European Court of Auditors. ${ }^{150}$ Similarly, the European Court of Auditors noted several shortcomings in the cooperation between the ECB and the SRB with regard both to crisis management and the preparatory phase. ${ }^{151}$

Second, the resolution authority may lack the relevant expertise and international standing to make full and efficient use of its new prerogatives. ${ }^{152}$ Originally, it was not set up to make assessments required by this new framework. As with most institutional problems, there are two radical solutions to address them. First, one could argue for consolidation of agencies. However, in this described setup, the fear of yet further powers granted to the ECB seems to render this option impossible. Second, the cooperation could be enhanced. In this respect, well-known recommendations to boost funding and training of such agencies should be repeated. Nevertheless, both of these solutions require investments and this could also prevent them from being implemented.

Finally, from a literal interpretation of the law, the Single Resolution Board lacks the legal mandate to act as a gatekeeper of financial stability or as a macro-prudential authority. The mandate of the SRB is inherently linked to

148 Martin Götz/Tobias Tröger/Mark Wabrenburg, "The next SSM Term: Supervisory Challenges Ahead”, SAFE White Paper 2019, p. 16.

149 Art. 8 BRRDII.

150 European Court of Auditors, Special Report: The operational efficiency of the ECB's crisis management for banks, 2018, p. 26.

151 Ibid. p. 26.

152 This is suggested by Karel Lannoo, "Stock take of the SRB's activities over the past years: What to improve and focus on? Banking Union Scrutiny. In-depth analysis requested by the ECON Commission”, CEPS Special Report, March 2019, 19. On the same Issue, see also European Court of Auditors, Special Report Single Resolution Board: Work on a challenging Banking Union task started, but still a long way to go, 2017. 
the fulfilment of the resolution objectives. ${ }^{153}$ It goes without say, resolution objectives only look at the effects of a resolution procedure and not at the preventive impact of the decision concerning MREL. In this regard, the BRRDII advances the MREL's functional understanding; however, the SRMRII did not bring about an equal advancement in the institutional set up. Paradoxically, these institutional pitfalls can be more easily overcome in Member States outside of the Banking Union, where the RA is often embedded in the National Central Bank.

\section{Conclusion}

In this article we discussed the legal and economic nature of minimum requirement for own funds eligible liabilities. The analysis highlights a dichotomy between the ex-post and ex-ante nature of MREL. The requirement was first thought and conceptualised as an "ex-post" tool to ensure that a resolution action could be effectively implemented if a bank became "failing or likely to fail". However, our functional analysis revealed that from an ex-ante perspective minimum capital requirement and MREL do not differ dramatically, as both limit the freedom of the bank in deciding upon its funding strategy. This unveiled the second nature of MREL, that has effect also ex-ante, in good times, and not only contingently on resolution.

Building on this theoretical construct, the article discusses the legal innovation brought about by the 2019 Banking Reform Package. The analysis revealed that the new regulatory framework better recognises the double nature of MREL and is better fit to unveil its preventive potential. In particular, the analysis focused on the interplay between capital requirements and MREL; the rules on MREL determination, both qualitative and quantitative; and the novel set of powers to address a MREL breach.

The new legal framework enabled the preventive potential of MREL and made it a valuable complement to the rest of the preventive toolkit already available. MREL can have positive effects on micro-prudential risk prevention, allowing the resolution authority to limit excessive risk-taking very far from distress. Furthermore, MREL can also have a macro-preventive component, since the BRRDII provision allow to graduate the quantity of MREL taking into consideration counterparty risk as well as the financial cycle.

Finally, the article discusses the potential pitfalls that may render the new framework inefficient. The analysis highlights that the current institutional fra- 
mework may jeopardise the full application of the MREL framework, especially considering the complex cooperation that the competent and resolution authority should undertake. This represents a decisive impediment especially for the Euro Area countries, where a similar level of coordination and cooperation between the SRB and the ECB seems a far-reaching goal. Moreover, the SRB lacks a proper preventive legal mandate. Paradoxically, in non-EA countries, where the RA is often embedded in the national Central Bank, these problems may be more easily overcome. 